\title{
Technologies for attention to diversity: a bibliometric study
}

\author{
Ma Isabel Vidal Esteve, Diana Marín Suelves, José Peirats Chacón, M. Isabel Pardo \\ Baldoví \\ Grupo de Investigación CRIE, Departament de Didàctica i Organització Escolar, \\ Universitat de València, Spain.
}

\begin{abstract}
In these last decades, digital systems and playful dynamics have penetrated the inclusive education field, in some cases to attend the diversity of the classroom as a whole and, in others, to study in a specific way the use of technologies in students with special needs. About this topic, on the following pages we study the trends of the research carried out through a bibliometric analysis of the scientific production in the Scopus database, which includes an amount of 59 articles, published between 1999 and 2019. The results indicate an increase in the last years of the presence of scientific publications in journals in the field of Social Sciences. Furthermore, data show that the number of articles and the impact of these is scarce, that the predominant country in the publications is United States and that in the co-occurrence of the terms the agents involved in the process, technology and inclusive practices stand out as relevant issues, which implies the urgent need for digital teacher training.
\end{abstract}

Keywords: Technology; school; disabilities; inclusion. 


\section{Introduction}

Information and communication technologies (ICT) have been firmly established in our society and their use is becoming more and more frequent in the educational field. From the political institutions, the use of technology in educational centers and, specifically, in classroom practices, has been included in legal regulations too (Area et al., 2014; San Martín, Peirats \& Gallardo, 2014; Waliño, Peirats, Pessoa \& Vidal, 2018). Numerous studies highlight the advantages of ICT, not only for neurotypical students, but also in supporting special needs students in an ordinary educational context (AEDENAEE, 2013), and they insist on the use of these tools to favor educational inclusion. We understand that inclusive education must "provide educational attention that favors the maximum possible the development of all students and the cohesion of all members of the community" (Spanish Ministry of Education, Culture and Sport, 2017, p.1) and that ICTs are tools capable of favoring it, with better and new learnings, pedagogical innovations, organizational changes, and especially, with the creation of asynchronous training opportunities (Cabero \& Fernández, 2014).

In this sense, we consider that teacher training is necessary, both initial and permanent (Marín, Vidal, Peirats \& San Martín, in press), to obtain the maximum potential of the technological devices, and that allow to implement innovative practices based on different methodological approaches, strategies and organizational models that contribute to creating inclusive environments and to offering opportunities for equity.

For all these reasons, the purpose of our work is to carry out a bibliometric analysis of papers published in Scopus database, without a temporal filter, to know the trends of scientific production on the use of technology in educational inclusion of people with disabilities, specifically, in the field of Social Sciences.

\section{Method}

For the analysis of the scientific activity carried out in educational inclusion of students with disabilities mediated by technology, a bibliometric analysis has been executed (Tomás-Gorriz and Tomás-Casterá, 2018). The focus has been on the texts available in Scopus database, because it has been considered several authors (Granda, Alonso, García, Solano, Jiménez \& Aleixandre, 2013, Hernández, Sans, Jové \& Reverter, 2016) as the most complete in terms of time coverage and number of titles by area. This has allowed us to know the status of the issue, the impact and the dissemination of studies, and successful experiences based on scientific evidence, specifically through a mesoanalysis (King, 1987) focused on Social Sciences field. 
Terms used for the research in Scopus have been: disabilities \& inclusion \& technology \& school, and all documents deposited until January 8th of 2019 have been included. The number of results obtained was 108 , so it was considered more appropriate to limit it to Open access documents and to Social Sciences area, with these restrictions an amount of 59 documents were obtained. In addition, to analyse the topics worked and their representation, the program VosViewer (Van Eck \& Waltman, 2011) was used and we have established, as categories of analysis, indicators of scientific productivity, collaboration and impact (Aleixandre et al., 2017). Furthermore, we have identified landmarks approached in these documents.

\section{Results}

Regarding scientific productivity, it is worth highlighting, first of all, the number of documents found, without a temporal filter nor limitation to a specific area of study. There are a total of 108 results published between 1999 and 2019; and our selection (59 documents) represents $54.6 \%$ of the total amount of researched published in Scopus in the last 20 years. As shown in Figure 1, the increase in the number of publications made in recent years is considerable and the trend is growing. Proof of this is that already, in the first week of 2019, there is a document in Scopus on this subject (Fage, Consel, Etchegoyhen, Amestoy, Bouvard, Mazon \& Sauzéon, 2019).

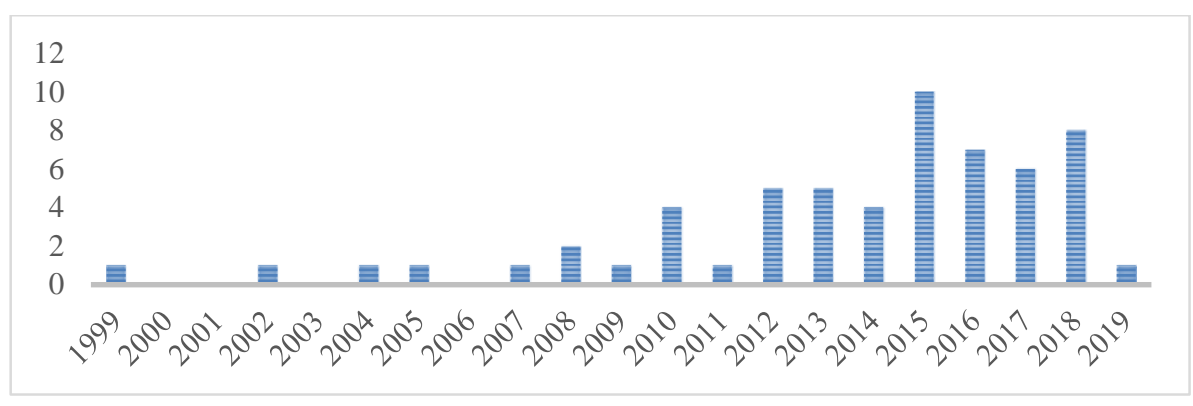

Figure 1. Frequency of Scopus publications. Source: Personal compilation.

Secondly, regarding the analysis of bibliometric size by country, United States stands out as the predominant place, followed by Brazil and United Kingdom. As shown in Figure 2, these three countries are responsible for more than half of the publications in this field. Spain belongs to the group of countries that have only one contribution (Afonso, Tadeu \& Batanero, 2017), as well as Belgium, Canada, China or Denmark; that's why it does not appear in the figure; we have only represented the countries more than two publications. 


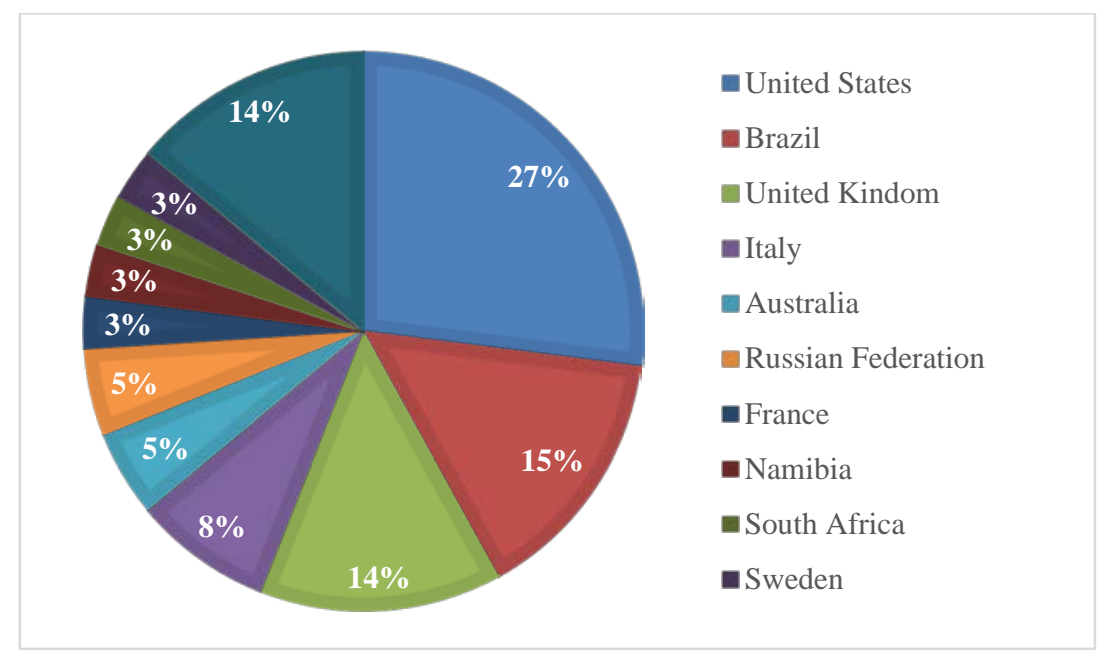

Figure 2. Publications per country. Source: Personal compilation.

According to collaboration, Table 1 presents the data regarding the number of authors who sign each document. It stands out that $75 \%$ of the texts are signed by two or more authors, so the collaboration index is high and the most usual are papers signed by two authors (37\%). Seven is the maximum number of signatory authors registered, as in the recent article by Slemmons, Anyanwu, Hames, Grabski, Mlsna, Simkins \& Cook (2018).

Table 1. Number of signatories per document.

\begin{tabular}{cc}
\hline Number of authors & \% \\
\hline 1 & 25 \\
2 & 37 \\
3 & 14 \\
4 & 8 \\
5 & 8 \\
6 or more & 8 \\
\hline Source: Personal compilation.
\end{tabular}

In regard to the impact, Table 2 shows the number of citations received for the analysed documents, as we can see there are great differences between them. It stands out that more than $30 \%$ of the documents do not have any citations and that it is independent of the year of publication. Half of the documents have less than 10 citations and among the most cited 
documents, an article on ASD (Wehman, Schall, Carr, Targett, West \& Cifu, 2014) and three reviews (Istenic \& Bagon, 2014; Alquraini, 2012) are found. Within these reviews, the only one with more than 100 citations is located, in which Ferguson (2008) analyses the features of inclusion from an international perspective.

Table 2. Number of citations.

\begin{tabular}{cc}
\hline Citations received & \% \\
\hline None & 34 \\
$1-10$ & 51 \\
$10-20$ & 8 \\
$21-30$ & 3 \\
$31-40$ & 2 \\
More tan 100 & 2 \\
\hline Source: Scopus. Personal compilation.
\end{tabular}

Finally, in terms of the main areas of research in this field, the existence of three clusters stands out, which revolve around the subjects implicated and their limitations (student, child, person, disability, need, teacher), technology (technology, assistive technology, accessibility) and inclusive practice (social inclusion, support, strategy, inclusive education, barrier) (Figure 3).

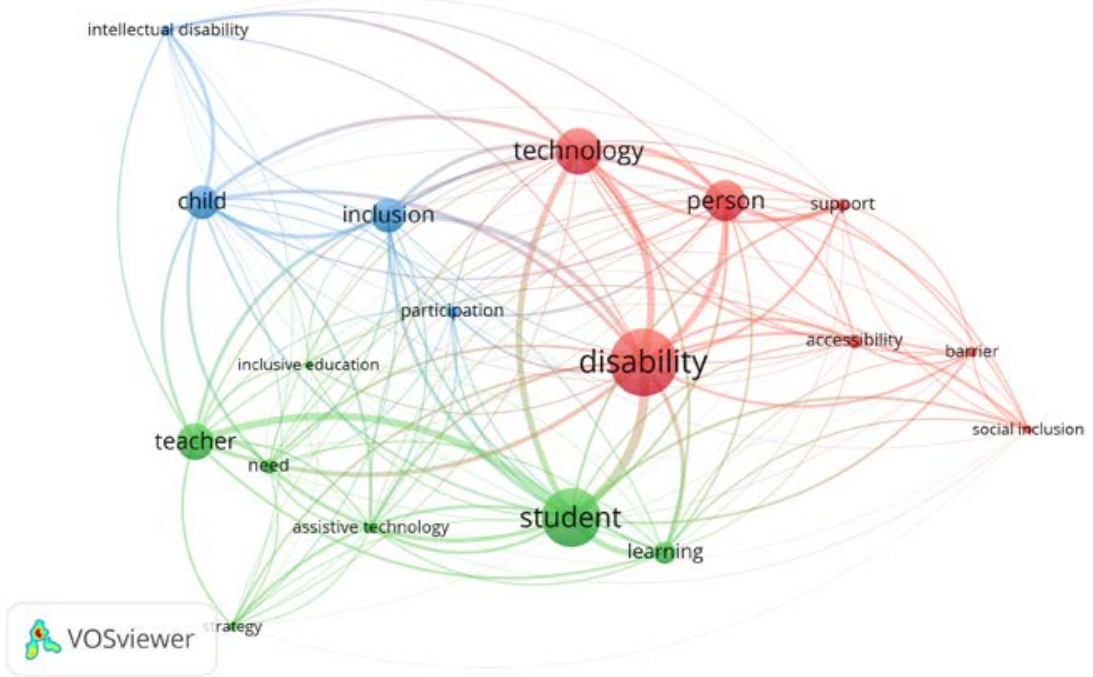

Figure 3. Co-ocurrences map. 


\section{Discussion}

The aim of the study was to analyse trends in research on technologies for attention to educational diversity in the field of Social Sciences. For this, a bibliometric analysis of the scientific production deposited in the Scopus database was carried out. In which a selection of indicators of scientific productivity, collaboration and impact, as well as the cooccurrence of prevailing terms have been studied in the documents.

Firstly, the results published and available in the Scopus database indicate that interest and effort by the study on the subject has been increasing in recent times, so much that in the first week of 2019 a document was already registered. In addition, we emphasize that, although studies are also reflected from other areas of knowledge, such as Medicine, Computer Science, Engineering and Psychology, the predominant area is the Social Sciencies, English as the prevailing language (followed by Portuguese), and United States (followed by Brazil and United Kingdom) the overriding country.

Secondly, analysing the characteristics of co-authorship and collaboration, through the number of signatories, it should be noted that most of the documents were signed by two or more authors, which indicates that the collaboration structures and networks in the scientific community, on the subject, are relatively high.

If we look at the impact, it is noteworthy that a high percentage of the works did not get any citations and that more than half of the documents have less than 10, which implies that the impact of most of the studies analysed has been limited. However, it is also remarkable that one of the papers, which studied international tendencies regarding the challenge of attending to the class as a whole and, at the same time, the individuality of each one of the students through technology, was cited 114 times .

Finally, regarding to the main research lines, data from this study allow us to identify the existence of three large clusters: the subjects involved (child, adolescent, student), technology (ICT, technology, assistive technology, information and communication) and inclusive practices (teaching, inclusion, disabilities, special education) as fundamental elements in the educational process.

The process of integrating technologies into teaching-learning practices in the different educational modalities is a reality, and also in inclusive school (Al-Harthi \& Emam, 2018; Young \& Courtad, 2016). In this situation, the initial training of future professionals in education (Barber, 2018, Hall \& Theron, 2016) is essential. There are numerous studies suggesting that teachers have not received a true qualification throughout their training, to incorporate the technologies to his professional activity (Carruba, 2016; Fiorini \& Manzini, 2016). They would also need, according to others (Lyons \& Tredwell, 2015, O'Rouke, 2015), the implementation, by the administrations of compulsory models about the use of 
technologies for inclusive education. In conclusion, as expected, most of publications conclude that there are many possibilities in technologies as an activating element of other strategies that establishes a bridge between students and their learning, and that increases their motivation, interest and performance (Istenic \& Bagon, 2014; Young \& Courtad, 2016) in a context such as the current one in which digitization covers all areas of society. However, and finally, we ask ourselves if educational institutions are trained for the challenges involved in the coalescence of technology at inclusive process. As future lines, we should think about the impact of high or low number of publications on educational diversity; does it represents the educational reality of inclusion? Are related low number of publications with disabled students with fewer educational resources? Or are school and research going different ways?

\section{Financing and acknowledgment}

To Conselleria de Educación, Investigación, Cultura y Deporte for the promotion of scientific research, technological development and innovation in Comunitat Valenciana. This paper is based on the results of phase I of project GV/2018/074.

To Ministerio de Ciencia, Innovación y Universidades by the grant to Formación del Profesorado Universitario.

\section{References}

AEDEANEE (2013). Tecnologías de la información y la comunicación para la inclusión. Avances y oportunidades en los países europeos. Dinamarca: Agencia Europea para el Desarrollo de la Educación del Alumnado con Necesidades Educativas Especiales.

Afonso, N., Tadeu, P., \& Batanero, J. M. F. (2017). Adaptation of curricular activities as a form of inclusion - an experience report. Turkish Online Journal of Educational Technology, October Special Issue INTE, 192-198.

Aleixandre, R., González, J., Castelló, L., Navarro, C., Alonso, A., Vidal, A., Lucas, R. \& Sixto, A. (2017). Bibliometría e indicadores de actividad científica (V). Indicadores de colaboración. Acta Pediatr Esp., 75(9-10): 108-113.

Al-Harthi, A. S. A., \& Emam, M. (2017). Leadership of technology in inclusive practice. In 6th International Conference on Information and Communication Technology and Accessibility (ICTA). Arab League Educational, Cultural and Scientific Organization (ALECSO), Oman.

Alquraini, T. (2012). Critical components of successful inclusion of students with severe isabilities: Literature review. International Journal of Special Education, 27(1), 42-59.

Area, M. et al. (2014). Las políticas educativas TIC en España después del Programa Escuela 2.0: las tendencias que emergen. Revista Latinoamericana de Tecnología Educativa-RELATEC, 13(2), 11-33. doi: https://doi.org/10.17398/1695-288X.13.2.11. 
Barber, W. (2018). Inclusive and accessible physical education: rethinking ability and disability in pre-service teacher education. Sport, Education and Society, 23(6), 520532.

Carruba, M. C. (2016). Classroom Management And Inclusion: Pedagogical And Technological Approach. TOJET: Turkish Online Journal of Educational Technology, 11, 462-468.

Fage, C., Consel, C., Etchegoyhen, K., Amestoy, A., Bouvard, M., Mazon, C., \& Sauzéon, H. (2019). An emotion regulation app for school inclusion of children with ASD: Design principles and evaluation. Computers and Education, 131, 1-21. doi:10.1016/j.compedu.2018.12.003

Ferguson, D. L. (2008). International trends in inclusive education: The continuing challenge to teach each one and everyone. European Journal of Special Needs Education, 23(2), 109-120. doi:10.1080/08856250801946236

Fiorini, M. L. S., \& Manzini, E. J. (2016). Difficulties and Successes Physical Education Teachers Experience with School Inclusion. Revista Brasileira de Educação Especial, 22(1), 49-64.

Granda, J. I., Alonso, A., García, F., Solano, S., Jiménez, C. A., \& Aleixandre, R. (2013). Ciertas ventajas de Scopus sobre Web of Science en un análisis bibliométrico. Revista española de documentación científica, 36(2), 1-11.

Hall, A. M., \& Theron, L. (2016). How school ecologies facilitate resilience among adolescents with Intellectual Disability: Guidelines for teachers. South African Journal of Education, 36(2), 1-13.

Hernández-González, V., Sans-Rosell, N., Jové-Deltell, M. C., \& Reverter-Masia, J. (2016). Comparación entre Web of Science y Scopus, estudio bibliométrico de las revistas de anatomía y morfología. International Journal of Morphology, 34(4), 13691377.

Istenic, A., \& Bagon, S. (2014). ICT-supported learning for inclusion of people with special needs: Review of seven educational technology journals, 1970-2011. British Journal of Educational Technology, 45(2), 202-230. doi:10.1111/bjet.12086

King, J. (1987). A review of bibliometric and other science indicators and their role in research evaluation. Journal of information science, 13(5), 261-276.

Lyons, C. D., \& Tredwell, C. T. (2015). Steps to implementing technology in inclusive early childhood programs. Computers in the Schools, 32(2), 152-166.

Marín, D., Vidal, M.I., Peirats, J. \& San Martín, A. (en prensa). Competencia Digital transversal en la formación del profesorado, análisis de una experiencia. Revista Innoeduca.

O'Rourke, J. (2015). Inclusive schooling: if it's so good-why is it so hard to sell?. International Journal of Inclusive Education, 19(5), 530-546.

San Martín, Peirats \& Gallardo (2014). Centros educativos inteligentes: luces y sombras sobre las políticas de transferencia de tecnología y las prácticas docentes. Profesorado: Revista de currículum y formación del profesorado, 3(18), 63-79. 
Slemmons, K., Anyanwu, K., Hames, J., Grabski, D., Mlsna, J., Simkins, E., \& Cook, P. (2018). The impact of video length on learning in a middle-level flipped science setting: Implications for diversity inclusion. Journal of Science Education and Technology, 27(5), 469-479. doi:10.1007/s10956-018-9736-2

Tomás-Górriz, V., \& Tomás-Casterá, V. (2018). La Bibliometría en la evaluación de la actividad científica. Hospital a Domicilio, 2(4), 145-163.

Van Eck, N. J., \& Waltman, L. (2011). Text mining and visualization using VOSviewer. arXiv preprint arXiv:1109.2058.

Wehman, P., Schall, C., Carr, S., Targett, P., West, M., \& Cifu, G. (2014). Transition from school to adulthood for youth with autism spectrum disorder: What we know and what we need to know. Journal of Disability Policy Studies, 25(1), 30-40. doi:10.1177/1044207313518071

Young, M. C., \& Courtad, C. A. (2016). Inclusion and students with learning disabilities. In General and special education inclusion in an age of change: impact on students with disabilities (pp. 13-29). Emerald Group Publishing Limited. 